\title{
Molecular and immunological analysis of genetic prostate specific antigen (PSA) vaccine
}

\author{
Jong J Kim ${ }^{1,2}$, Neil N Trivedi², Darren M Wilson ${ }^{2}$, Sundarasamy Mahalingam², Lake Morrison ${ }^{3}$, \\ Anthony Tsai ${ }^{2}$, Michael A Chattergoon'2, Kesen Dang², Mamata Patel'2, Lois Ahn', \\ Jean D Boyer ${ }^{2}$, Ara A Chalian ${ }^{3}$, Hubert Shoemaker ${ }^{4}$, Thomas Kieber-Emmons ${ }^{2}$, \\ Michael A Agadjanyan ${ }^{2}$ and David B Weiner ${ }^{2}$
}

${ }^{1}$ Department of Chemical Engineering; ${ }^{2}$ Department of Pathology and Laboratory Medicine; ${ }^{3}$ Department of Otorhinolaryngology/ Head and Neck Surgery, University of Pennsylvania, Philadelphia, Pennsylvania 19104, USA; ${ }^{4}$ Centocor, Inc. Malvern, Pennysylvannia 19355, USA

\begin{abstract}
Nucleic acid immunization has been investigated as immunotherapy for infectious diseases as well as for treating specific types of cancers. In this approach, nucleic acid expression cassettes are directly inoculated into the host, whose transfected cells become the production source of novel and possibly immunologically foreign protein. We have developed a DNA vaccine construct which encodes for PSA by cloning a cDNA for PSA into a mammalian expression vector under control of a CMV promoter. We investigated and characterized the immunogenicity of PSA DNA expression cassettes in mice. PSA-specific immune responses induced in vivo by immunization were characterized by enzyme-linked immunosorbent assay (ELISA), $T$ helper proliferation cytotoxic $T$ lymphocyte (CTL), and flow cytometry assays. We observed a strong and persistent antibody response against PSA for at least 180 days following immunization. In addition, a significant $T$ helper cell proliferation was observed against PSA protein. Using synthetic peptides spanning the PSA open frame, we identified four dominant $T$ helper epitopes of PSA. Furthermore, immunization with PSA plasmid induced MHC Class I CD8 $+\mathrm{T}$ cell-restricted cytotoxic $\mathrm{T}$ lymphocyte response against tumor cell targets expressing PSA. The prostate represents a very specific functional organ critical for reproduction but not for the health and survival of the individual. Understanding the immunogenicity of PSA DNA immunization cassettes offers insight into the possible use of this tumorassociated antigen as a target for immunotherapy. These results demonstrate the ability of the genetic PSA to serve as a specific immune target capable of generating both humoral and cellular immune responses in vivo.
\end{abstract}

Keywords: PSA; epitope mapping; DNA vaccination; immune responses; prostate cancer; immunotherapy

\section{Introduction}

Prostate cancer is the most common malignancy in American men and is the second leading cause of cancer related death in the male population (Boring et

Correspondence: DB Weiner

Received 16 September 1997; revised 19 November 1997; accepted 19 November 1997 al., 1994). It was estimated that 244000 men would be diagnosed with prostate cancer and 40400 men would die of the disease in 1995 in the United States (Wingo et al., 1995). In general, prostate cancer appears in adult life. The average age of patients diagnosed with prostate cancer between 1973 and 1987 was 67 years, and the incidence of prostate cancer climbs rapidly at approximately fifty years of age (Gilliland and Keys, 1995). The age-related death rate for prostate cancer has been roughly constant over the past several decades. The causes of prostate cancer remain obscure; both environmental factors and genetic predisposition may contribute to developing the disease (Dong et al., 1995; Pienta and Esper, 1993).

Defining standard treatment of clinically localized prostatic carcinoma involves considerable controversy. The three approaches most commonly employed today include surgical excision of the prostate and seminal vesicles, external beam irradiation, and androgen deprivation. Using the histologic grade of biopsy specimens and clinical staging, one can predict the likelihood of nodal and further metastatic spread, and in turn the likelihood of successful surgical excision (Garrick and Fair, 1996). Unfortunately, even early treatment through surgery or radiation therapy can lead to unwanted side effects such as impotence and urinary incontinence (O'Donnell and Finan, 1989; Zagars, 1995). Traditional surgical androgen deprivation (e.g. castration with adrenalectomy, hypophysectomy) has been largely replaced by hormonal therapy (e.g. LHRH analogues, aminoglutethimide). Pharmacologic ablation or blockade often induces remission, but often only short duration (Labrie et al., 1993).

Recent advances in diagnosis, particularly in the measurement of prostate specific antigen (PSA) in the blood, have led to earlier diagnosis of the disease (Catalona et al., 1991; Stamey et al., 1987). PSA is a serine protease and a human glandular kallikrein product of 240 amino acids (Wang et al., 1982; Watt et al., 1986). PSA is secreted by both normal and transformed epithelial cells of the prostate gland, with substantially more secreted by cancer cells (Wang et al., 1982). Since PSA expression appears to be limited to prostate cells, it is a widely used marker for the diagnosis of prostate cancer (Labrie et al., 1992). This tissue specificity of PSA makes it a potential target antigen for the development of immunotherapies against prostate cancer (Armbruster, 1993; Hodge et al., 1995). 
Several immunotherapeutics against cancer have already been investigated. Examples include the injection of live, irradiated, and autologous tumor cells transfected with cytokines (Sandra, 1994; Vieweg et al., 1994). In addition, a recombinant vaccinia virus engineered to express PSA and autologous dendritic cells loaded with peptide sequences of prostate cancer antigens have been investigated as possible vaccines (Hodge et al., 1995; Tjoa et al., 1996).

In this study, we report on the characterization of an immunologically-based therapeutic strategy utilizing PSA DNA expression cassettes as a novel therapy for the treatment of prostate cancer. Nucleic acid immunization induces antigen-specific immune responses following injection of non-replicating plasmids directly into a host target tissue (Boyer et al., 1997; Davis et al., 1993; Fynan et al., 1993; Kim et al., 1997a,b; Kim and Weiner, 1998; Lu et al., 1995; Tang et al., 1992; Ulmer et al., 1993; Wang et al., 1993). Once injected, these non-replicating transcription units drive the synthesis of specific foreign proteins within the inoculated host. These hostsynthesized foreign proteins then become subject to immune surveillance, resulting in antigen-specific cellular and humoral immune responses, without the associated risk of viral pathogenesis. Our goal is to use DNA immunization to elicit host immune responses against cells producing PSA. Specifically, we developed a DNA vaccine construct which encodes for human PSA by cloning a gene for PSA into expression vectors under control of a cytomegalovirus (CMV) promoter. As a first test we immunized mice intramuscularly with these DNA vaccines and investigated the in vivo immune responses generated.

Our immunization strategy using PSA plasmid induced both PSA-specific humoral and cellular immune responses. We observed a strong and persistent antibody response against PSA for at least 180 days following immunization. In addition, we observed a significant $\mathrm{T}$ helper cell proliferation against PSA protein and identified the dominant $T$ helper epitope regions of PSA. Furthermore, immunization with PSA plasmid induced MHC Class I $\mathrm{CD} 8+\mathrm{T}$ cell-restricted cytotoxic $\mathrm{T}$ lymphocyte response against tumor cell targets expressing PSA. Using this technique we have identified novel $\mathrm{T}$ helper epitopes present within the PSA gene sequence supporting induction of a broad immune response. These results demonstrate the potential utility of targeting PSA as a testable immunotherapy against prostate cancer.

\section{Results}

Construction and in vitro expression of PSA construct

The complete coding sequence of human PSA was cloned into pCDNA3 vector (Figure 1a). The resulting plasmid pCPSA was verified by sequence analysis. The plasmid was then transfected into HeLa cells and tested for expression by immunoprecipitation (Figure 1b) (Mahalingam et al., 1995; Ray et al., 1989). The immunoprecipitated sample was analysed by SDSPAGE (12\%). As expected, we observed an expression of PSA as a protein with the molecular weight of $30 \mathrm{kD}$.
In vivo expression of PSA by immunohistochemistry

We then immunized female Balb/c mice intramuscularly with $50 \mu \mathrm{g}$ of pCPSA or a control plasmid. The mice were sacrificed after $72 \mathrm{~h}$ and the quadriceps muscles were removed and frozen. The frozen sections were cut onto slides, stained with $\alpha$-PSA antibody, and observed under microscope. Figure 2a shows a muscle slide stained with hematoxylin and eosin (H\&E) stain. As shown in Figure 2b, we observed an expression of PSA on the slides from pCPSA immunized mice. The slide from control immunized mice did not show expression of PSA (Figure 2c).

\section{Generation of humoral response}

Mice received two DNA immunizations intramuscularly (50 $\mu \mathrm{g}$ each day) at days 0 and 14 . Sera from immunized mice were collected at $0,30,60$ and 180 days post-immunization and analysed for specific antibody responses against PSA protein by ELISA at $1: 100,1: 400,1: 800$ and $1: 1600$ dilution. The pre-
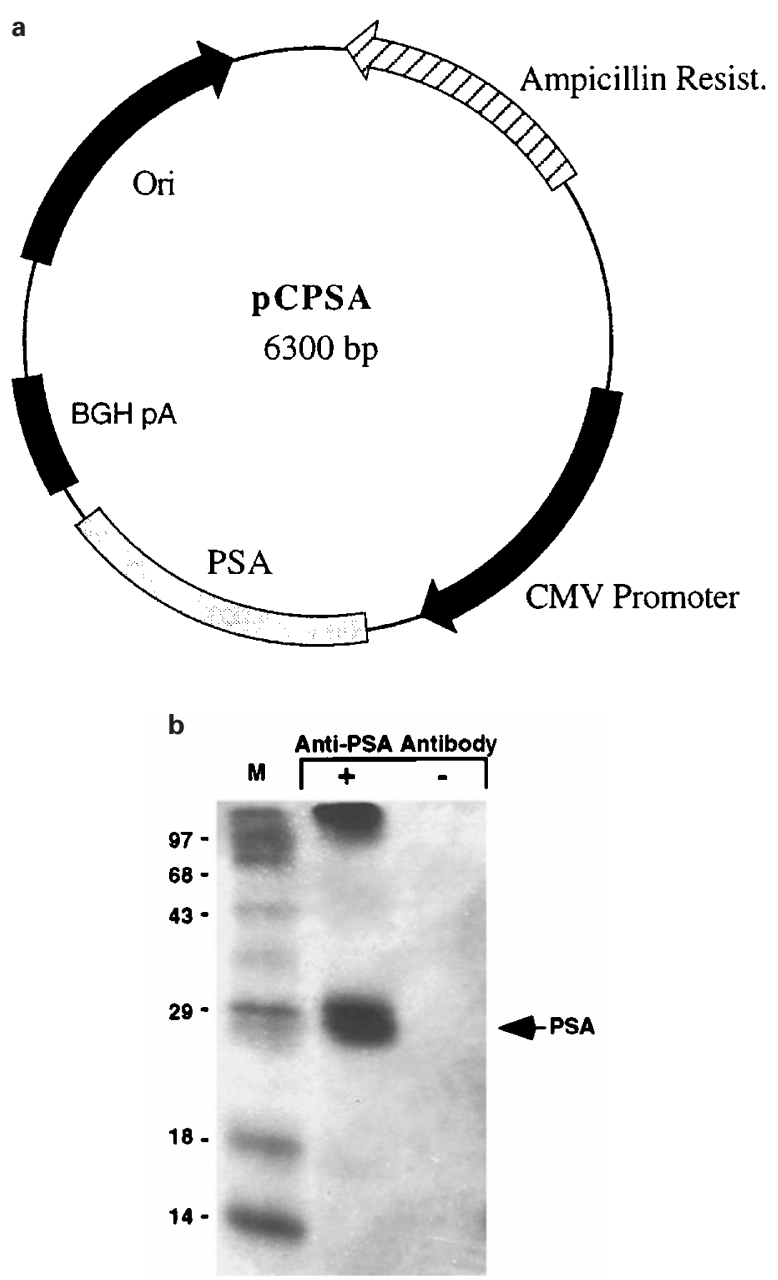

Figure 1 Construction and in vitro expression of pCPSA. (a) The complete coding sequence of human PSA was cloned into pCDNA3 vector. (b) Expression of PSA was assayed by immunoprecipitation with $(+)$ or without $(-) \alpha$-PSA antibodies (kindly provided by Dr D Knight of Centocor). The immunoprecipitated sample was analysed by SDS-PAGE $(12 \%)$. The PSA band at the molecular weight of $30 \mathrm{kd}$ is indicated by the arrow 

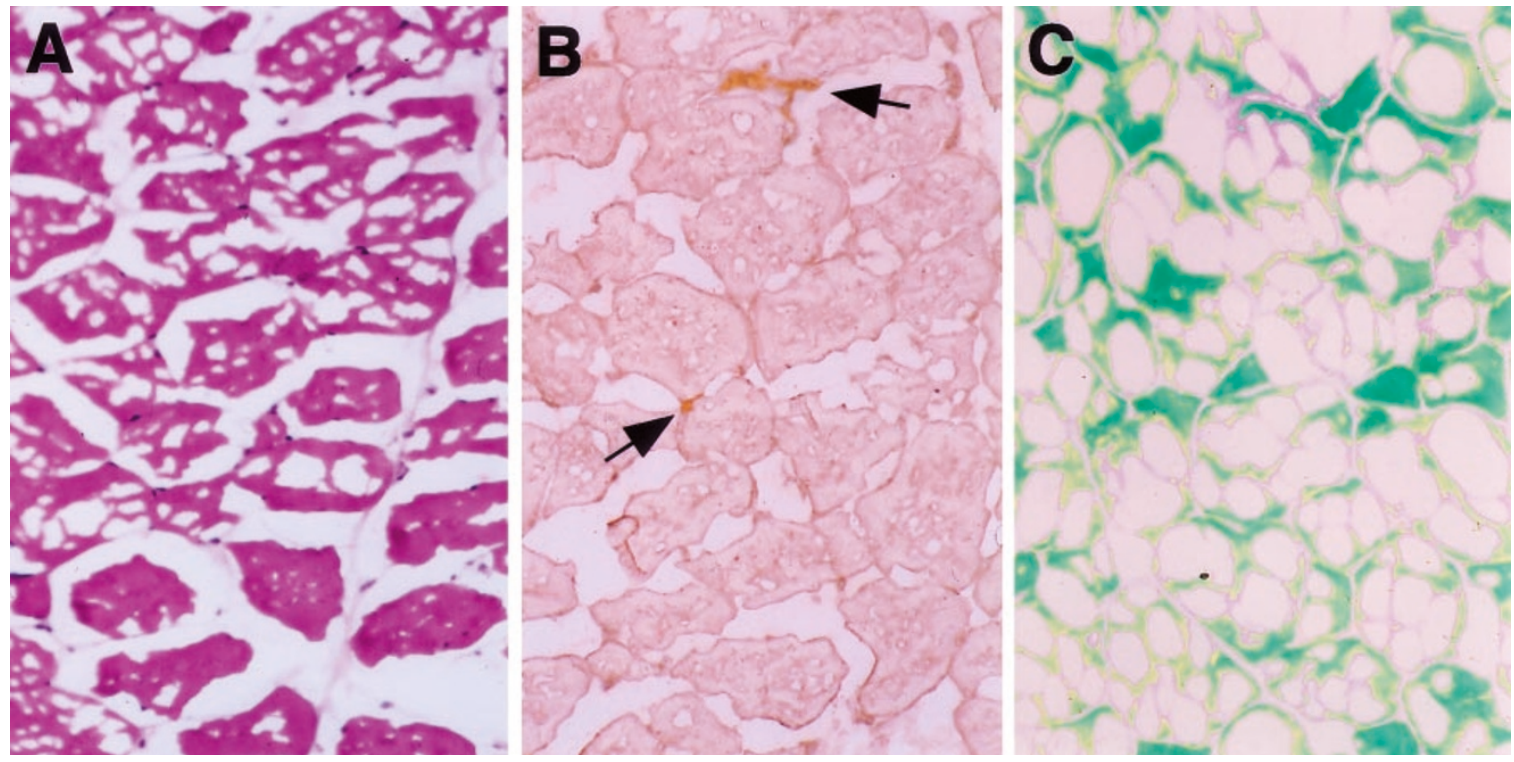

Figure 2 Immunohistochemical assay for expression of PSA on muscle cells. Frozen muscle sections were prepared from DNA injected animals and stained with $\alpha$-PSA antibody. Positive antigen expression is illustrated by PSA-specific staining and representative examples of in vivo expression are highlighted with black arrows. (a) A representative muscle slide illustrated with hematoxylin and eosin (H\&E) stain, where the nuclei are shown in blue stain and the cytoplasm is shown in red stain. (b) A slide from a leg immunized with pCPSA and stained with $\alpha$-PSA antibody. (c) A slide from control plasmid immunized leg stained with $\alpha$-PSA antibody

injection sera collected at day 0 did not show any PSAspecific antibody response. However, at $1: 100$ dilution, the PSA-specific antibody response was detectd at 30 and 60 days post-immunization (Figure 3a). Furthermore, even at the 1:1600 dilution, the humoral response persisted 180 days from the initial immunization. As shown in Figure $3 \mathrm{~b}$, the reciprocal titer of PSA-specific antibody response increased to 1600 at day 60 and remained at this titer level even after 180 days without any additional immunization.

\section{Generation of $T$ helper response}

Mice received two DNA immunizations (50 $\mu \mathrm{g}$ each) separated by 2 weeks. At one week after the boost injection, the mice were euthanized, the spleens harvested and the lymphocytes isolated and tested for $\mathrm{T}$ cell proliferation. Figure 4 shows the proliferation assay results for the mice immunized with pCPSA vaccine. Recombinant PSA protein $(5 \mu \mathrm{g} / \mathrm{ml}$ and $1 \mu \mathrm{g} / \mathrm{ml})$ was plated in each well for specific stimulation of $\mathrm{T}$ cell proliferation. $5 \mu \mathrm{g} / \mathrm{ml}$ of lectin PHA was used as a polyclonal stimulator positive control. As shown, a background level of proliferation was observed in the control group with a stimulation index of 1.3. However, a significant level of $\mathrm{T}$ cell proliferation was observed at both $5 \mu \mathrm{g} / \mathrm{ml}$ and $1 \mu \mathrm{g} / \mathrm{ml}$ concentrations with stimulation index of 4.8 and 2.3 , respectively.

\section{Mapping of $T$ helper cell epitopes}

Identification of PSA peptides which are dominant in the interaction with $\mathrm{T}$ helper epitopes would be important in designing potential immune therapies against tumor antigens. We prepared a panel of peptides 15 amino acids long which span the entire region of PSA protein (Figure 5a). Mice received two DNA immunizations (50 $\mu \mathrm{g}$ each) separated by two weeks. At one week after the boost injection, the mice were euthanized, spleens harvested, and lymphocytes isolated and tested for $\mathrm{T}$ cell proliferation against peptides at $5 \mu \mathrm{g} / \mathrm{ml}$ and $1 \mu \mathrm{g} / \mathrm{ml}$ concentrations. From these experiments, we identified several immunodominant peptide regions. We observed significant level of $\mathrm{T}$ helper cell proliferation against four amino acid regions, 43-54, 97-114, 166-186 and 217-234 (Figure 5b). Other amino acid regions did not result in specific $\mathrm{T}$ helper cell proliferative responses. Four immunodominant peptide regions were plotted on the previously reported 3-dimensional structure of PSA (Figure 5c) (Bridon and Dowell, 1995; Vihinen, 1994; Villoutreix et al., 1994). For the most part, the immunodominant regions consisted of surface-exposed amino acids.

\section{Generation of cytotoxic $T$ lymphocyte response}

Induction of cell-mediated immunity is thought to be an important feature for any candidate immunotherapeutic vaccine for cancer. CTLs would play a critical role in targeting and destroying tumor cells. Accordingly, a CTL assay was performed on spleen cells harvested from pCPSA immunized and control mice by measuring chromium release from specific and nonspecific targets. To find specific lysis of targets, the percentage of lysed non-specific target cells was subtracted from the percentage of lysed specific target cells. Two weeks after DNA immunization (50 $\mu \mathrm{g}$ each), the mice were euthanized and spleens were harvested. The results for the CTL assay are shown in Figure 6a. Only a background level of specific killing was observed from the control animals without immunization. On the other hand, the animals immunized with PSA showed a significant level of PSA-specific CTL response. Greater than $16 \%$ specific killing of PSA-transfected targets was observed at a 


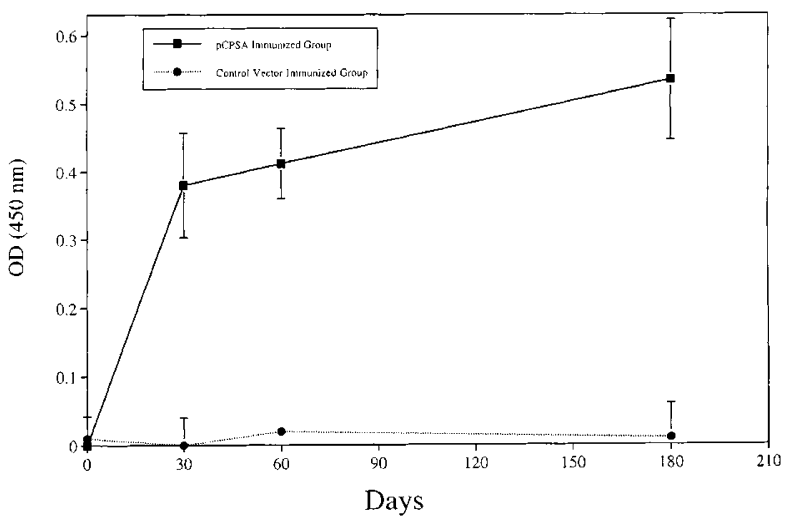

b

Reciprocal Titration of PSA-Specific Antibody Response

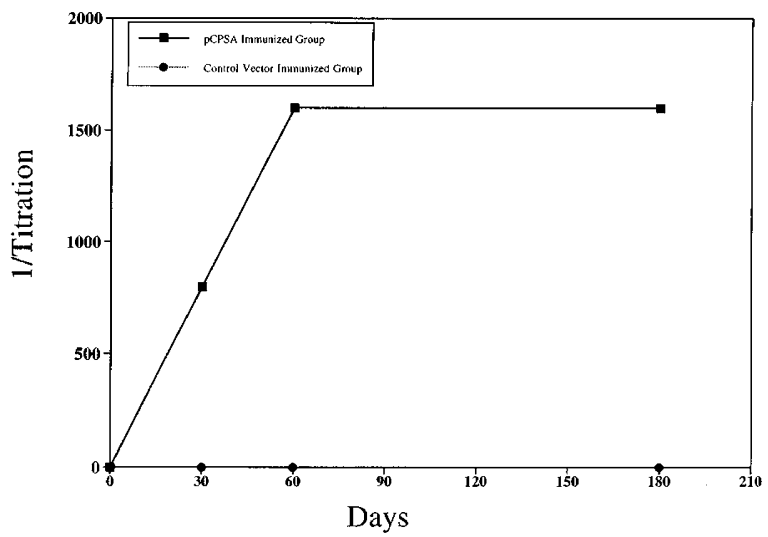

Figure 3 PSA-specific antibody response following co-immunization. (a) $50 \mu \mathrm{g}$ of pCPSA expression cassette and control vector was injected intramuscularly at day 0 and boosted once at day 14 . The sera samples were collected at $0,30,60$, and 180 days postimmunization and assayed for PSA-specific antibody at $1: 100$, $1: 400,1: 800$, and $1: 1600$ dilutions. (a) At $1: 100$ dilution, PSAspecific antibody response was detected at 30 and 60 days postimmunization and the response was persistent after 180 days from the initial immunization. The error bars represent the standard deviation of the results from the immunized animals $(n=4)$. (b) The reciprocal titer of PSA-specific antibody response increased to 1600 at day 60 and was maintained at this titer level after 180 days without any additional immunization. The experiment was repeated two additional times with similar results

$50: 1$ effector to target (E:T) ratio and titered out to $11 \%$ specific lysis at a 12.5:1 E:T ratio.

\section{$M H C$ class I restricted $C T L$}

In order to determine if the level of lysis from the CTL assay was due to a CD8 $+\mathrm{T}$ cell and MHC class 1restricted stimulus, a CTL assay was performed with $\mathrm{CD} 8+\mathrm{T}$ cells removed from the effector cell population by complement lysis. This assay was performed on the isolated splenocytes following in vitro stimulation with PSA-specific stimulators as described. As shown in Figure 6b, the removal of $\mathrm{CD} 8+\mathrm{T}$ cells using complement lysis resulted in complete suppression of antigen-specific CTL response to a background level. These results indicate that this PSA-specific cytotoxic activity was MHC class Irestricted and CD8 $+\mathrm{T}$ cell dependent.

\section{T Helper Cell Proliferation Response}

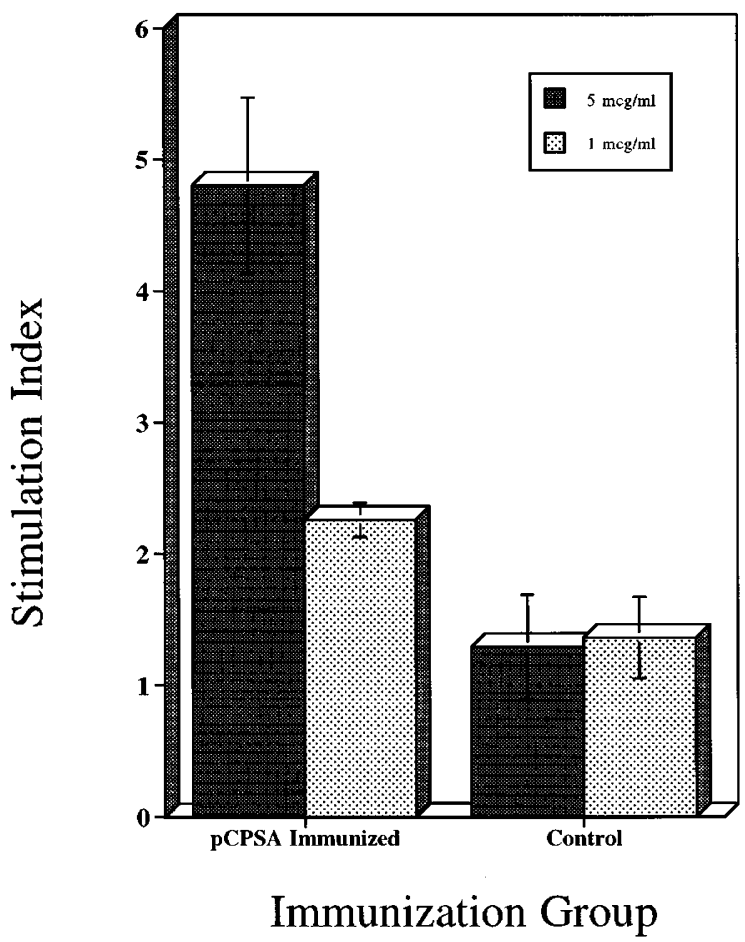

Figure $4 \mathrm{~T}$ helper cell proliferation responses induced by pCPSA immunization. Two weeks after immunization with $50 \mu \mathrm{g}$ of pCPSA spleens were collected from immunized mice. The splenocytes were isolated and tested against recombinant PSA protein at 5 and $1 \mu \mathrm{g} / \mathrm{ml}$ concentrations. The error bars represent the standard deviation of the results from the immunized animals $(n=4)$. The experiment was repeated two additional times with similar results. The proliferative responses were significant for pCPSA immunized groups at both 5 and $1 \mu \mathrm{g} / \mathrm{ml}$ of PSA protein (with $P$ value $<0.01$ at $5 \mu \mathrm{g} / \mathrm{ml}$ protein concentration)

\section{Cytokine analysis}

The level of various cytokines released by immune cells reflects the direction and magnitude of the immune response. For example, IFN- $\gamma$ is a prototypical Th1type cytokine which is intricately involved in the regulation of $\mathrm{T}$ cell-mediated cytotoxic immune response (Mogensen and Virelizier, 1987). On the other hand, IL-4 is a Th2-type cytokine. We collected supernatant samples from splenocyte cultures which were stimulated specifically in preparation for CTL assay and tested them for the release of IFN- $\gamma$ and IL4. As shown in Figure 7a, we observed a significantly higher level of IFN- $\gamma$ from the group immunized with pCPSA at $4.6 \mathrm{ng} / \mathrm{ml}$. On the other hand, only $0.2 \mathrm{ng} /$ $\mathrm{ml}$ of IFN- $\gamma$ was observd from the supernatant from the control group. When we examined the IL-4 release from these supernatants, we found a similar level of IL-4 at 16 and $11 \mathrm{pg} / \mathrm{ml}$ from the pCPSA immunized and control groups, respectively (Figure 7b). This 20fold increase in the level of IFN- $\gamma$ released by the pCPSA-immunized group over the control group indicates a high level of Th1 T cell stimulation in the pCPSA-immunized group and supports the cellular 
nature of the response observed in the CTL assays as well as the immune activation phenotype observed.

Flow cytometry analysis

To further characterize the cellular effects of DNA immunization, we performed FACS analysis on the cells harvested from the spleen. Following one DNA immunization (50 $\mu \mathrm{g}$ each), the mice were euthanized the spleens harvested, and the lymphocytes isolated and analysed by FACS. Figure 8 shows the FACS results from the double-staining of the splenocytes with antibodies for CD28 and CD69 with antibodies for CD4 or CD8. As shown, we observed a minor increase in the percentage of CD4 $+\mathrm{CD} 28+\mathrm{T}$ cells (from $8.6-$ $9.2 \%$ ) and CD $4+\mathrm{CD} 69+\mathrm{T}$ cells (from $7.5-8.4 \%$ )

\section{Mapping of Th Epitope Using PSA Peptides}

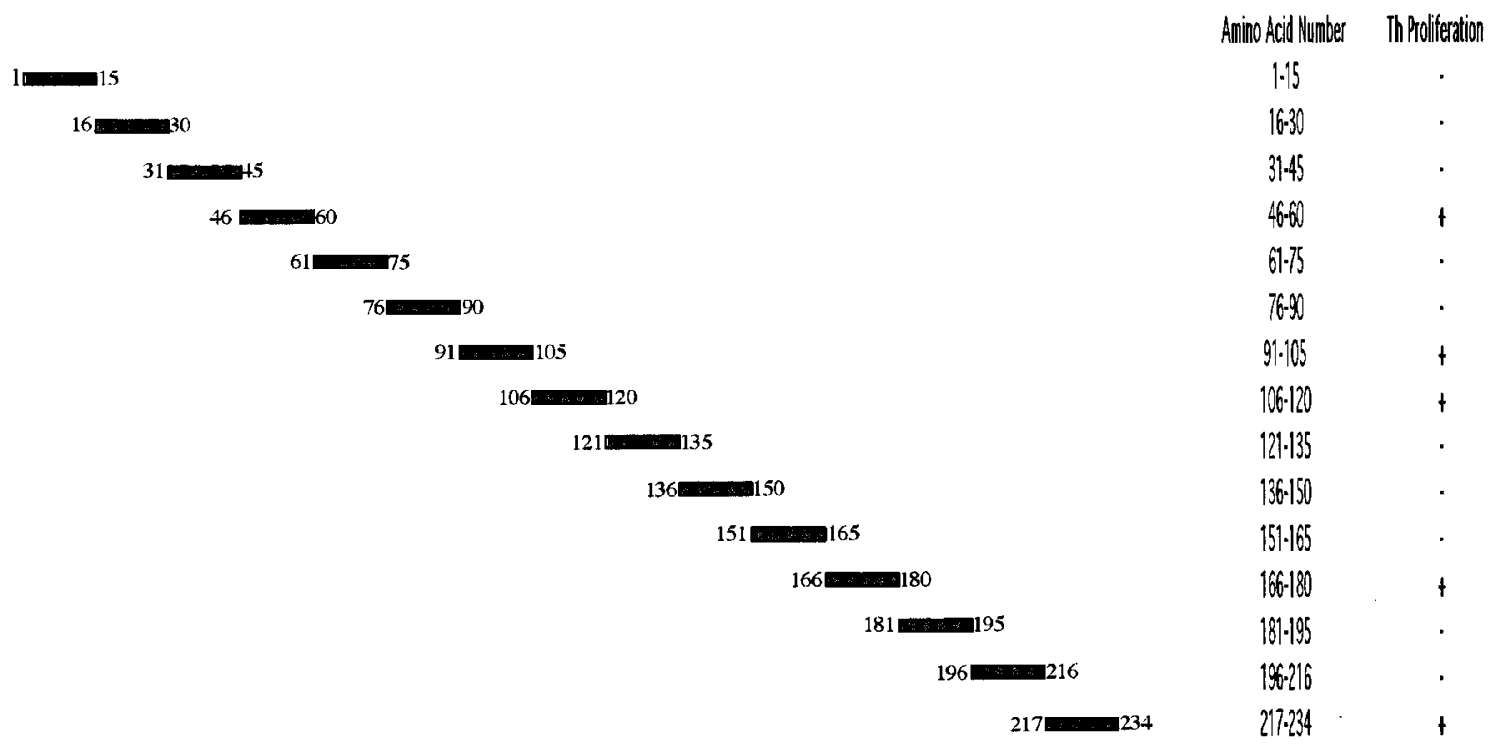

T Helper Response Mapping of PSA Peptides

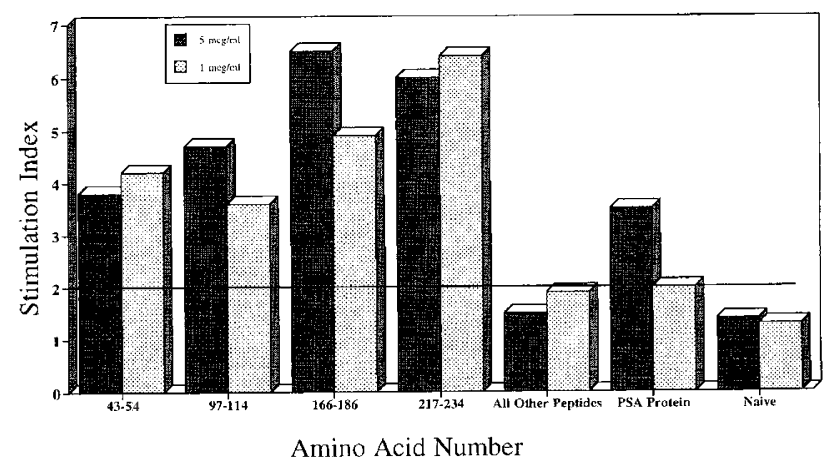

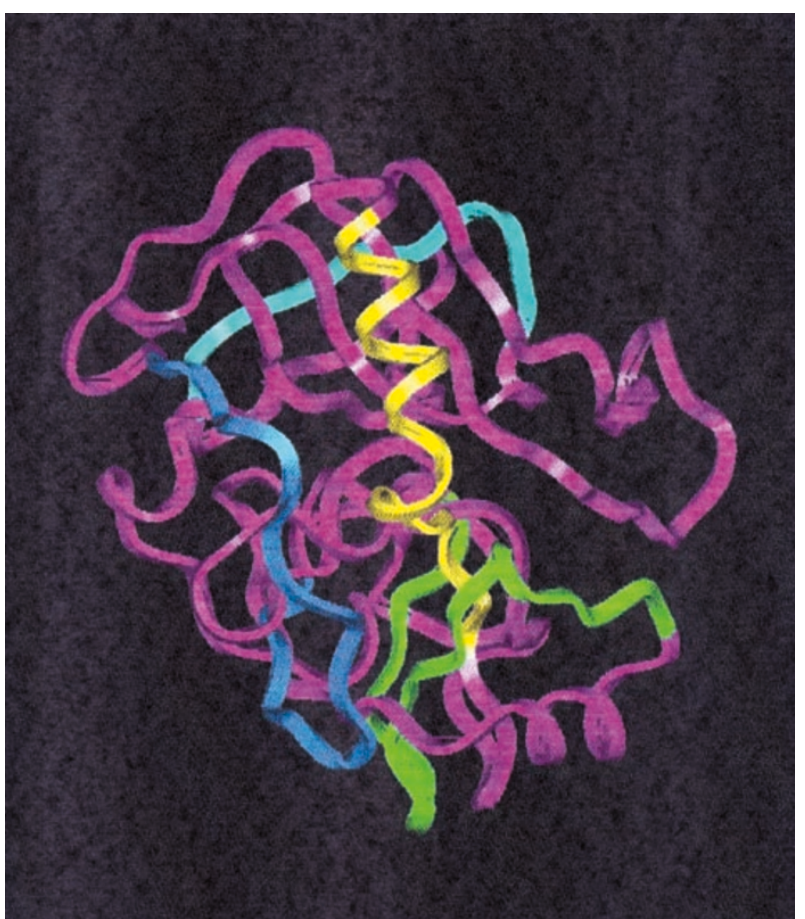

Figure 5 Mapping of $\mathrm{T}$ helper cell epitopes. Two weeks after immunization with $50 \mu \mathrm{g}$ of pCPSA spleens were collected from immunized mice $(n=4)$. The splenocytes were isolated and tested against a panel of peptides 15 amino acids long which span the entire region of PSA protein at $5 \mu \mathrm{g} / \mathrm{ml}$ and $1 \mu \mathrm{g} / \mathrm{ml}$ concentrations. The peptide sequences which resulted in a proliferative response which was greater than the SI of two are indicated by the ' + ' sign. (b) From these experiments, the immunodominant peptide regions were identified as amino acids 43-54, 97-114, 166-186 and 217-234. (c) PSA peptide sequence was plotted on a 3dimensional structure of PSA. The immunodominant peptide regions are: 43-53 (light blue), 97-114 (dark blue), 166-186 (green), and 217-234 (yellow). The experiment was repeated three additional times with similar results 
PSA-Specific CTL Response (With CD8+ T cells)

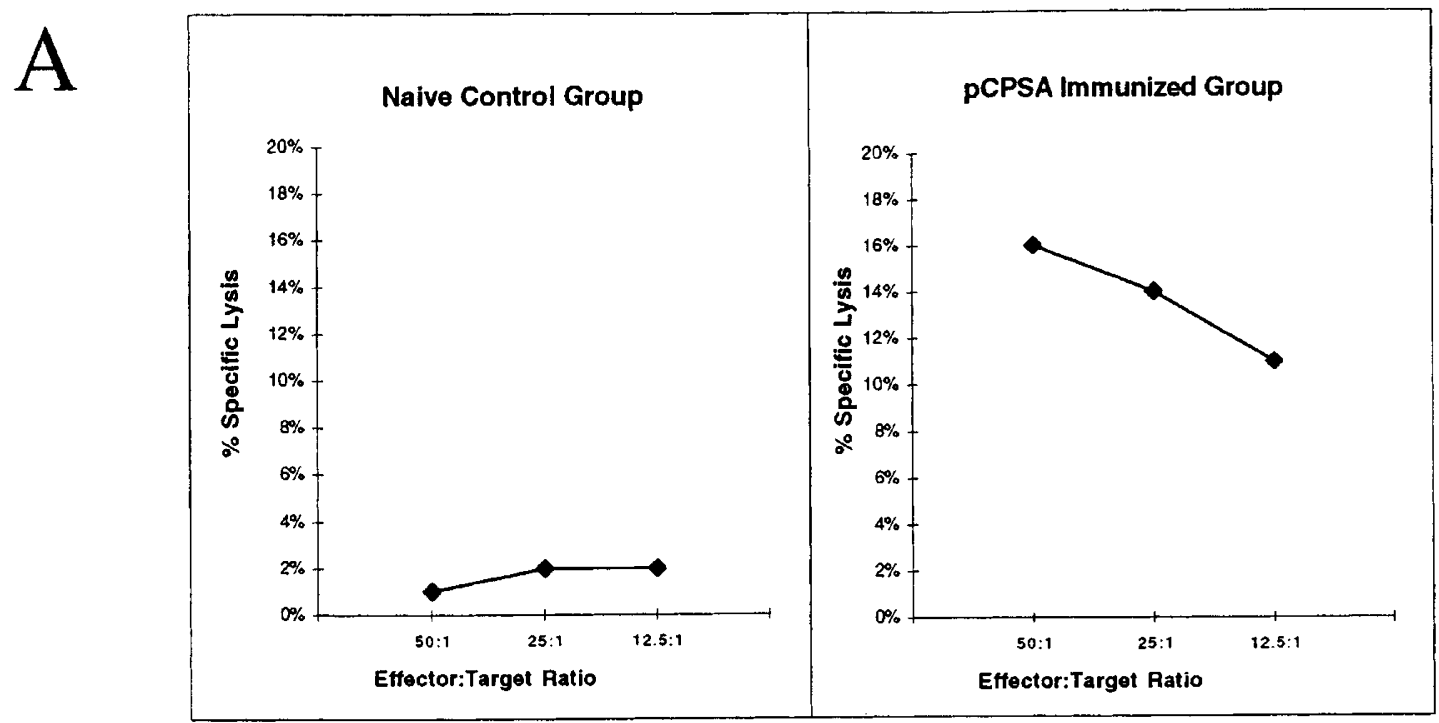

PSA-Specific CTL Response (Without CD8+ T cells)

B

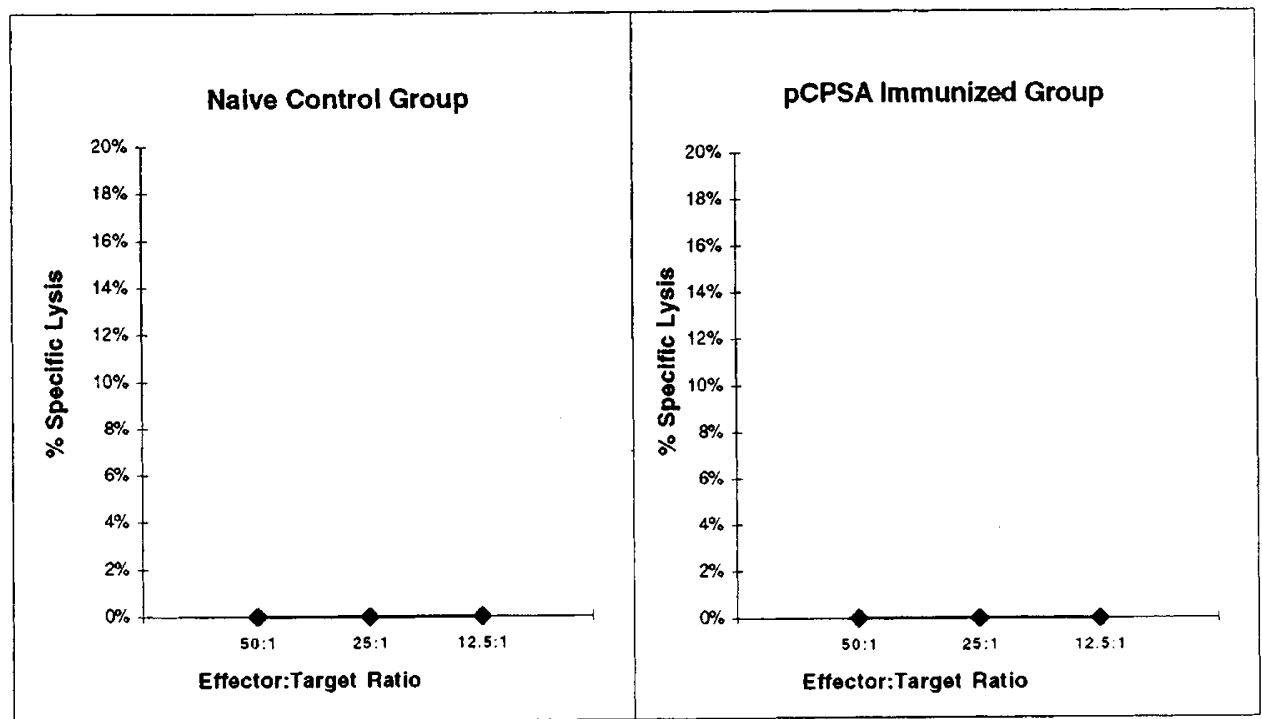

Figure 6 Cytotoxic T lymphocyte responses induced by pCPSA immunization. Two weeks after immunization with $50 \mu \mathrm{g}$ of pCPSA or control vector, spleens were collected from immunized mice $(n=4)$. The splenocytes were isolated and tested for CTL response using target cells transfected with pCPSA. A CTL assay was performed with the inclusion of CD8 + T cells and the removal of CD8 $+\mathrm{T}$ cells by complement lysis. Effector cells were prepared as described with the presence of CD8 $+\mathrm{T}$ cells $(\mathbf{a})$ and the removal of $\mathrm{CD} 8+\mathrm{T}$ cells $(\mathbf{b})$. The experiment was repeated two additional times with similar results

from the pCPSA immunized group in comparison to those of the control group. On the other hand, we observed almost doubling in both populations of $\mathrm{CD} 8+\mathrm{CD} 28+\mathrm{T}$ cells (from $4.6-7.3 \%$ ) and $\mathrm{CD} 8+\mathrm{CD} 69+\mathrm{T}$ cells (from $4.8-7.2 \%$ ) in the group immunized with pCPSA. This result is likely related to the CTL response and cytokine profile changes.

\section{Discussion}

One of the most actively investigated immunotherapies for the treatment of cancer is vaccines. For a vaccine to prevent disease progression, particularly to prevent tumor cell progression, both humoral and cellular immunity may be required for effective activity. Such vaccines should be able to generate memory cells which survey for specific tumor antigens on a long-term basis. Several approaches for tumor immunotherapy have been employed thus far. Some tumor vaccines have consisted of inactivated tumor cells or cell lysates delivered in vivo with adjuvants while others have consisted of injecting live irradiated whole autologous tumor cells transfected with cytokine (Dranoff et al., 1993; Tepper et al., 1989), costimulatory molecule (Coughlin et al., 1995), or MHC (Plautz et al., 1993) genes. These studies have reported varying degrees of success in eliciting tumor-specific immune responses.

More specifically to prostate cancer immunotherapies, autologous whole tumor cell vaccines transfected 
with interleukin-2, interferon- $\gamma$, or GM-CSF have been reported to elicit tumor-specific immune responses in rats (Sandra, 1994; Vieweg et al., 1994). Other vaccination approaches include using a recombinant vaccinia virus engineered to express PSA and using autologous dendritic cells loaded with peptide se-
A)

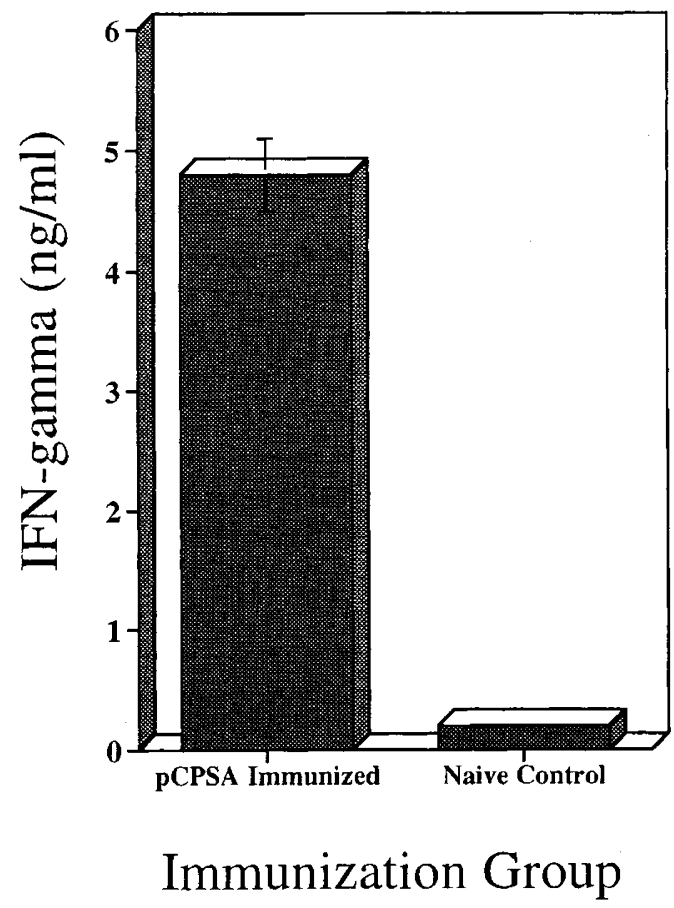

B)

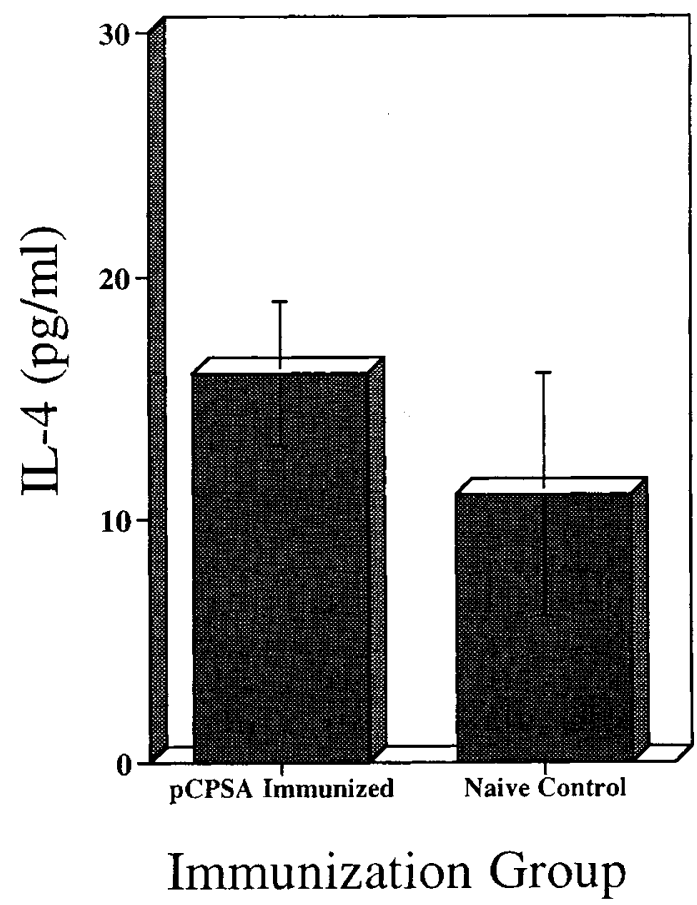

Figure 7 Supernatants from splenocytes stimulated for CTL responses (Figure 6) were collected and tested for production of (a) IFN- $\gamma$ and (b) IL-4

Control Group
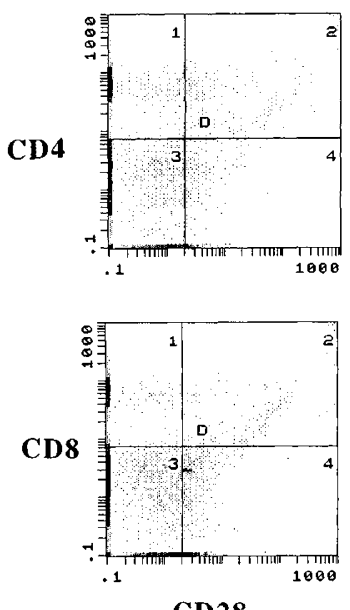

CD28
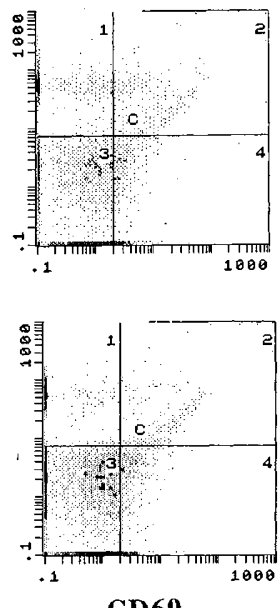

PSA Immunized Group
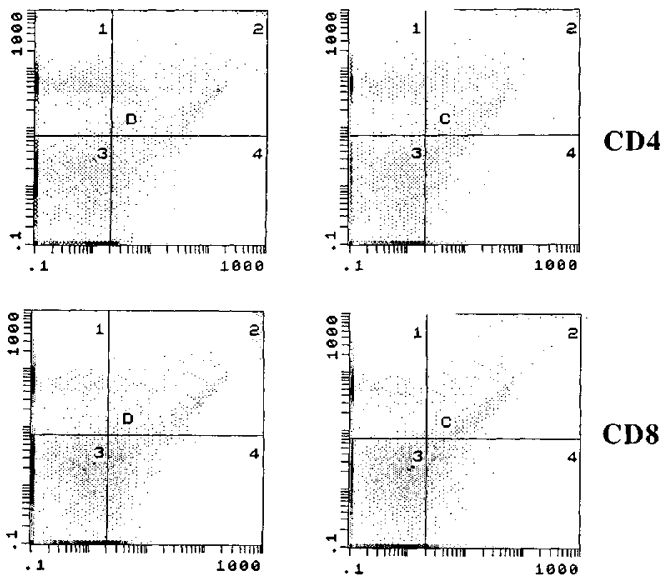

CD28

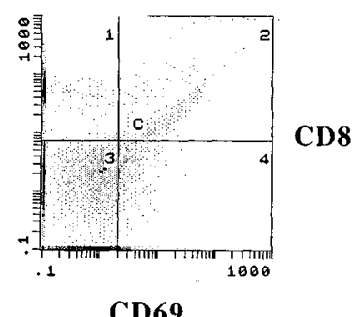

\begin{tabular}{|c|c|c|c|c|}
\hline \multirow{2}{*}{ Immunization Group } & \multicolumn{4}{|c|}{ Percentage Cell Population (\%) } \\
\cline { 2 - 5 } & CD4+CD28+ & CD4+CD69+ & CD8+CD28+ & CD8+CD69+ \\
\hline Control Group & 8.6 & 7.5 & 4.6 & 4.8 \\
\hline PSA Immunized Group & 9.2 & 8.4 & 7.3 & 7.2 \\
\hline
\end{tabular}

Figure 8 FACS analysis on splenocytes. Two weeks after a single DNA immunization with $50 \mu \mathrm{g}$ of pCPSA, the lymphocytes were isolated from the harvested spleens $(n=4)$ and analysed by FACS. The lymphocytes were double-stained with antibodies for CD28 or CD69 and antibodies for CD4 or CD8. The experiment was repeated with similar results 
quences of prostate cancer antigens (Hodge et al., 1995; Tjoa et al., 1996).

We and others have developed a new strategy for the production of immunotherapy against infectious diseases as well as the treatment of specific types of cancers (Agadjanyan et al., 1997; Davis et al., 1993; Kim et al., 1997b; Tang et al., 1992; Ulmer et al., 1993; Wang et al., 1993). This strategy is fundamentally different from previous vaccine approaches. Instead of employing killed or attenuated viruses, killed cancer cells, or proteins derived from viruses or tumors, our strategy utilizes nucleic acid expression cassettes (plasmids) which are directly inoculated into the host. These expression cassettes serve to transfect the individual who becomes the protein source for production of novel and possibly immunologically foreign material. It is this in vivo manufactured custom antigen which serves to induce the generation of an immune response.

This DNA immunization technology results in significant levels of protein production in the inoculated individual and evokes broad immune responses including the hallmark immune response of cellular immunity as well as those of humoral immunity (Bright et al., 1996; Conry et al., 1994; Geissler et al., 1997; Wang et al., 1995). Our group has reported on the use of this technology to produce immune responses in not only rodents, but also in non-human primates (Boyer et al., 1996, 1997). In addition, we initiated the first human trials for DNA vaccines. The preliminary results of these studies reveal immune enhancement and no clinical or laboratory adverse effects measured in three dosage groups $(30,100,300 \mu \mathrm{g}) \quad(\mathrm{RR}$ MacGregor, 1998).

The prostate represents a very specific function organ which does not produce life sustaining compounds. Thus, the development of a host immune response against these tumor specific antigens would be expected to have limited immunological consequences for the host due to the limited nature of prostate antigen expression. In this context it represents an ideal target for this type of immunotherapy. In addition, earlier works have shown that host immune responses against non-immunogenic tumors could be enhanced by the immune therapies (Dranoff et al., 1993; Townsend, 1993). We have developed a DNA vaccine construct which encodes for human PSA by cloning a cDNA for PSA into an expression vector under control of a CMV promoter. We then determined the expression of $30 \mathrm{kD}$ PSA protein using immunoprecipitation following a transfection with pCPSA. We immunized mice intramuscularly with pCPSA construct and investigated the immune responses generated. In this first examination, immunization is similar to vaccination against foreign rather than self-antigen.

This immunization strategy induced both PSAspecific humoral and cellular immune responses. To protect an immunized individual from tumor progression, a vaccine may be required to elicit both humoral and cellular immunity. We observed a strong and persistent PSA-specific antibody response following immunization for a minimum of 180 days. In addition, pCPSA immunization induced significant cellular immunity. We observed a significant induction of $\mathrm{T}$ helper cell proliferation when stimulated with PSA protein. In addition, we also investigated the level of $\mathrm{T}$ helper cell proliferation using 15-mer PSA peptides and found the dominant $\mathrm{T}$ helper cell epitopes of PSA to be the amino acids $43-54,97-114,166-186$ and $217-$ 234. Induction of a $\mathrm{T}$ helper cell response is important since activation and proliferation of $\mathrm{T}$ helper cells play a critical role in inducing both a humoral immune response via $B$ cells and cellular immune response via CD8 + cytotoxic $\mathrm{T}$ cells. We also observed a significant level of PSA-specific CTL response which was restricted by MHC Class I CD8 $+\mathrm{T}$ cells. The ability to elicit antigen-specific CTL responses is especially relevant in the development of a cancer vaccine. $\mathrm{T}$ cell mediated responses, especially those of $\mathrm{CD} 8+$ cytotoxic $\mathrm{T}$ cells, have been postulated to be important in anti-tumor immunity. Here, we were able to induce CD8 + CTLs which were able to kill mouse tumor cells expressing human PSA. Relatedly, we observed that the level of IFN- $\gamma$ in the supernatant from pCPSA-immunized group was almost 25 times that of the control group while the level of IL-4 was comparable to that of the control group, supporting Th1 type $\mathrm{T}$ cell phenotype was induced by the vaccine.

We also conducted FACS analysis on the spleen cells from the immunized and control groups. The splenocytes prepared from the pCPSA immunized group had a moderate increase in the percentage of CD4 + CD28 + and CD4 + CD69 + T cells than those of control mice. On the other hand, a significantly greater percentage of $\mathrm{CD} 8+\mathrm{CD} 28+$ and CD8 + CD69 $+\mathrm{T}$ cells from the pCPSA immunized group was observed 14 days post-immunization. These results indicate that pCPSA immunization induced the activation of both CD4 + and CD8 $+\mathrm{T}$ cells, but it had a greater effect on the $\mathrm{CD} 8+$ population consistent with the Th1 cytokine profile as well as the CTL study results. CD28 is a receptor for CD80 and CD86 costimulatory molecules (Schwartz, 1992). CD28 is a disulfide-linked homodimer that is expressed on peripheral $\mathrm{T}$ lymphocytes and thymocytes, and the interaction between CD28 and costimulatory molecules augments $\mathrm{T}$ cell proliferation (Linsley et al., 1991; Stack et al., 1994). Thus, the up-regulation of CD28 could indicate a higher level of T cell activation. CD69, also known as Very Early Activation Antigen, is detected at low levels in inactivated naive lymphocytes (Sobel et al., 1993). However, enhanced expression is observed on both $\mathrm{B}$ and $\mathrm{T}$ cells following activation of these cells. Thus, a greater percentage of $\mathrm{T}$ cell population with CD28 and CD69 activation markers indicates a higher level of $\mathrm{T}$ cell activation in the immunized group.

A clinically relevant cancer vaccine should induce and stimulate the host immune system against antigens which are specific to the tumor cells. We observed that nucleic acid immunization strategy utilizing PSA DNA expression cassettes could induce PSA-specific immune responses which were persistent 180 days post-immunization. More importantly, we observed the ability of our PSA vaccine to elicit CD8 $+\mathrm{T}$ cell-dependent CTL responses against tumor target cells expressing human PSA. However, a complicating issue is host-antigenic tolerance to PSA which is beyond the scope of this study. These data support the potential importance of a genetic immunization strategy against prostate cancer and 
suggest that further evaluation of this approach is warranted.

\section{Materials and methods}

\section{Construction and expression of pCPSA DNA constructs}

DNA vaccine cassettes expressing PSA were constructed by cloning the complete coding sequence of PSA into pCDNA3 expression vector (Invitrogen, Inc., San Diego, CA) (Figure 1a). The expression of PSA by the pCPSA was assayed by immunoprecipitation. HeLa cells were transfected with pCPSA as previously described (Mahalingam et al., 1995; Ray et al., 1989). The cells were washed twice with PBS, starved for $1 \mathrm{~h}$ in DMEM lacking serum, methionine and cysteine, and then labeled with $200 \mu \mathrm{Ci}$ / $\mathrm{ml}(1200 \mathrm{Ci} / \mathrm{mmole})$ of ${ }^{35} \mathrm{~S}$ protein labeling mix (NEN/ DuPont). Labeled cells were lysed in $0.5 \mathrm{ml}$ of RIPA buffer (50 mM TrisHCl pH 7.6; $150 \mathrm{~mm} \mathrm{NaCl} ; 0.2 \%$ Triton $\mathrm{X}$ $100 ; 0.2 \%$ deoxycholic acid; $0.1 \%$ SDS and $1 \mathrm{~mm}$ PMSF) on ice and then clarified by centrifugation at 15000 r.p.m. for $10 \mathrm{~min}$. The clarified lysates were incubated with $\alpha$-PSA antibody (a kind gift from Dr D Knight of Centocor) for 90 min on ice. Protein A sepharose was added to antigenantibody complexes and mixed by shaking at $4{ }^{\circ} \mathrm{C}$ for $90 \mathrm{~min}$. The protein pellet was resuspended in $50 \mu \mathrm{l}$ of $1 \times$ sample buffer and heated at $100^{\circ} \mathrm{C}$ for $3-5 \mathrm{~min}$ after extensive washing in buffers containing high salt and BSA. A fraction of the protein sample was analysed by SDS $12 \%$-PAGE. For fluorography, gels were soaked in $1 \mathrm{M}$ sodium salicylate containing $10 \%$ glycerol for $15 \mathrm{~min}$, dried, and autoradiographed using Kodak X-omat-AR film.

\section{DNA inoculation of mice}

The quadriceps muscles of $6-8$ week old Balb/c mice (Harlan Sprague Dawley, Inc., Indianapolis, IN) were injected with $50 \mu \mathrm{g}$ of pCPSA DNA construct formulated in phosphate buffered saline (PBS) and $0.25 \%$ bupivacaine$\mathrm{HCl}$ (Sigma, St Louis, MO) (Kim et al., 1997b). The mice were housed in a temperature controlled, light-cycled room. Their care was under the guidelines of the National Institutes of Health and the University of Pennsylvania. The control mice were immunized with $50 \mu \mathrm{g}$ of pCDNA3 vector. Each set of studies was performed three times and a representative set of results is presented.

\section{Immunohistochemial assay for expression of PSA on muscle cells}

Mouse quadriceps muscles were inoculated with $50 \mu \mathrm{g}$ of pCPSA construct as described above. After $72 \mathrm{~h}$ the mice were sacrificed and the quadriceps muscles were removed. The fresh muscle tissue was then examined by frozen section immuno-peroxidase (FSIP) method using a streptavidin-biotin complex technique (Research Genetics, Huntsville, AL). Briefly, $6 \mu$ cryostat sections were cut and placed on ProbeOn Plus slides (Fisher Biotech, Pittsburgh, PA). The slides were fixed in acetone, washed, and air dried. The slides were then blocked with $1.5 \%$ goat serum (Vector Labs, Burlingame, CA) and incubated in primary antibody with human $\alpha$-PSA antibody diluted to a $1: 750$ at room temperature. They were then incubated with a biotinylated secondary antibody followed by an incubation with Streptavidin-Biotin HRP (Research Genetics, Huntsville, AL). Slides were then treated with DAB (Ventana Biotech, Tuscon, AZ) and counterstained with fast green. The slides were viewed with a Nikon
OPTIPHOT fluorescing microscope (Nikon Inc., Tokyo, Japan) using a $40 \times$ objective (Nikon Fluo 40X Ph3D2). Slide photographs were obtained using Nikon camera FX35DX with exposure control by Nikon UFX-II and Kodak Ektachrome 160T slide film.

\section{ELISA}

Fifty $\mu \mathrm{l}$ of purified PSA protein (Fitzgerald Industries, Concord, MA) diluted in $0.1 \mathrm{M}$ carbonate-bicarbonate buffer ( $\mathrm{pH} 9.5)$ to $2 \mu \mathrm{g} / \mathrm{ml}$ concentration was adsorbed onto microtiter wells overnight at $4{ }^{\circ} \mathrm{C}$ as previously described (Kim et al., 1997b). The plates were washed with PBS- $0.05 \%$ Tween-20 and blocked with $3 \%$ BSA in PBS with $0.05 \%$ Tween- 20 for $1 \mathrm{~h}$ at $37^{\circ} \mathrm{C}$. Mouse antisera were diluted with $0.05 \%$ Tween-20 and incubated for $1 \mathrm{~h}$ at $37^{\circ} \mathrm{C}$, then incubated with HRP-conjugated goat antimouse IgG (Sigma, St Louis, MO). The plates were washed and developed with $3^{\prime} 3^{\prime} 5^{\prime} 5^{\prime}$ TMB (Sigma) buffer solution. The plates were read on a Dynatech MR5000 plate reader with the optical density at $450 \mathrm{~nm}$.

\section{$T$ helper cell proliferation assay}

Lymphocytes were harvested from spleens and prepared as the effector cells by removing the erythrocytes and by washing several times with fresh media as described (Kim et al., 1997b). The isolated cell suspensions were resuspended to a concentration of $1 \times 10^{6}$ cells $/ \mathrm{ml}$. A $100 \mu \mathrm{l}$ aliquot containing $1 \times 10^{5}$ cells was immediately added to each well of a 96 well microtiter flat bottom plate. Purified PSA protein (Fitzgerald Industries) or 15-mer PSA peptides were added to wells in triplicate at the final concentration of $5 \mu \mathrm{g} / \mathrm{ml}$ and $1 \mu \mathrm{g} / \mathrm{ml}$. The cells were incubated at $37^{\circ} \mathrm{C}$ in $5 \% \mathrm{CO}_{2}$ for 3 days. One $\mu \mathrm{Ci}$ of tritiated thymidine was added to each well and the cells were incubated for $12-18 \mathrm{~h}$ at $37^{\circ} \mathrm{C}$. The plate was harvested and the amount of incorporated tritiated thymidine was measured in a Beta Plate reader (Wallac, Turku, Finland). To assure that cells were healthy, lectin PHA or Concanavalin A (Sigma) were used as a polyclonal stimulator postive control. Stimulation Index was determined from the formula:

\section{Stimulation Index $(\mathrm{SI})=$}

(experimental count/spontaneous count)

Spontaneous count wells include $10 \%$ fetal calf serum which serves as irrelevant protein control. The data was analysed statistically using a paired student $t$-test.

\section{Cytotoxic T lymphocyte assay}

To make a target cell line for CTL assay, pCPSA plasmid was transfected into mouse mastocytoma P815 cell lines (ATCC, Rockville, MD). The transfected cells were selected and the clones were verified by RT-PCR. A $5 \mathrm{~h}$ ${ }^{51} \mathrm{Cr}$ release CTL asay was performed using these target cells (P815-PSA). The effectors were stimulated with P815PSA cells which were fixed with $0.1 \%$ glutaraldehyde for $4-5$ days in CTL culture media at $5 \times 10^{6}$ cells per ml. CTL culture media consists of $1: 1$ ratio of Iscove's Modified Dulbecco Media (Gibco-BRL, Grand Island, NY) and Hanks' Balanced Salt Solution (Gibco-BRL) with 10\% fetal calf serum (Gibco-BRL) and 10\% RAT-T-STIM without Con A (Becton Dickinson Labware, Bedford, MA). A standard Chromium release assay was performed in which the target cells were labeled with $100 \mu \mathrm{Ci} / \mathrm{ml}$ $\mathrm{Na}_{2}{ }^{51} \mathrm{CrO}_{4}$ for $60-120 \mathrm{~min}$ and used to incubate with the stimulated effector splenocytes for $4-6 \mathrm{~h}$ at $37^{\circ} \mathrm{C}$. CTL lysis was determined at effector:target $(\mathrm{E}: \mathrm{T})$ ratios ranging from $50: 1$ to $12.5: 1$. Supernatants were harvested and counted on a LKB CliniGamma gamma-counter. Per cent 
specific lysis was determined from the formula:

$$
100 \times\left\{\frac{\text { experimental release }- \text { spontaneous release }}{\text { maximum release }- \text { spontaneous release }}\right\}
$$

Maximum release was determined by lysis of target cells in $1 \%$ Triton X-100 containing medium. An assay was not considered valid if the value for the 'spontaneous release' counts is in excess of $20 \%$ of the 'maximum release'.

The removal of $\mathrm{CD} 8+\mathrm{T}$ cells was conducted by complement lysis. The splenocytes were treated with $\alpha$-CD8 monoclonal antibody (Pharmingen) followed by incubation with rabbit complement (Sigma) for $45 \mathrm{~min}$ at $37^{\circ} \mathrm{C}$ as described (Kim et al., 1997a).

\section{Cytokine ELISA}

Supernatants from splenocytes stimulated for CTL responses were collected and tested for cytokine profile using an ELISA kit for IL-4 and IFN- $\gamma$ (Pharmingen). Briefly, plates were coated with mouse anti-IL-4 and antiIFN- $\gamma$ antibodies at $2 \mu \mathrm{g} / \mathrm{ml}$. After overnight incubation at $4{ }^{\circ} \mathrm{C}$ and washing, plates were blocked with $10 \%$ fetal bovine serum (FBS). Serially diluted supernatants from splenocytes stimulated for 4-5 days (see CTL methods) were added at $100 \mu \mathrm{l}$ per well. After incubation and

\section{References}

Agadjanyan MG, Wang B, Nyland SB, Weiner DB and Ugen KE. (1997). Curr. Top. Immunol. Micro., In Press.

Armbruster DA. (1993). Clin. Chem., 39, 181-195.

Boring CC, Squires TS and Tong T. (1994). Ca: a Cancer Journal for Clinicians, 44, 7-26.

Boyer J, Wang B, Ugen K, Agadjanyan MG, Javadian MA, Frost P, Dang K, Carrano R, Ciccarelli R, Coney L, Williams WV and Weiner DB. (1996). J. Med. Primatol., 25, 242-250.

Boyer JD, Ugen KE, Wang B, Agadjanyan MG, Gilbert L, Bagarazzi $M$, Chattergoon $M$, Frost $P$, Javadian A, Williams WV, Refaeli Y, Ciccarelli RB, McCallus D, Coney L and Weiner DB. (1997). Nature Med., 3, 526532.

Bridon DP and Dowell BL. (1995). Urology, 45, 801-806.

Bright RK, Beames B, Shearer $\mathrm{MH}$ and Kennedy RC. (1996). Cancer Res., 56, $1126-1130$.

Catalona WJ, Smith DS, Ratliff TL, Dodds KM, Coplen DE, Yuan JJJ, Petros JA and Andriole GL. (1991). New Engl. J. Med., 324, 1156.

Conry RM, LoBuglio AF, Kantor J, Schlom J, Loechel F, Moore SE, Sumerel LA, Barlow DL, Abrams S and Curiel DT. (1994). Cancer Res., 54, 1164-1168.

Coughlin CM, Wysocka M, Kurzawa HL, Lee WM, Trinchieri G and Eck SL. (1995). Cancer Res., 55, 49804987.

Davis H, Michel ML and Whalen RG. (1993). Human Mol. Genetics, 2, $1847-1851$.

Dong JT, Lamb PW, Rinker-Schaeffer CW, Vukanovic J, Ichikawa T, Isaacs JT and Barrett JC. (1995). Science, 268, $884-886$

Dranoff G, Jaffee E, Lazenby A, Golumbek P, Levitsky H, Brose K, Jackson V, Hamada H, Pardoll D and Mulligan RC. (1993). Proc. Natl. Acad. Sci. USA, 90, 3539-3543.

Fynan E, Webster R, Fuller D, Haynes J, Santoro J and Robinson H. (1993). Proc. Natl. Acad. Sci. USA, 90, $11478-11482$

Garrick MB and Fair WB. (1996). Annals Intern. Med., 125, $118-125$.

Geissler M, Gesien A, Tokushige K and Wands JR. (1997). J. Immunol., 158, $1231-1237$.

Gilliland FD and Keys CR. (1995). Cancer, 75, 295-315. washing, biotinylated anti-IL- 4 and anti IFN- $\gamma$ antibodies were used at $1 \mu \mathrm{g} /$ well. 2,2'-Azino-bis-(3-ethybenzthiazoline-6-sulfonic acid) (Sigma) was used for color development and the plates were read at OD $405 \mathrm{~nm}$ on a Dynatech MR5000 plate reader.

\section{Flow cytometry}

The splenocytes were isolated from the immunized mouse spleens and analysed by the fluorescence activated cell sorter $($ FACS $)$. The cells $\left(1 \times 10^{5}\right)$ were washed three times with FACS buffer (PBS containing $1 \%$ BSA and $0.1 \%$ sodium azide) and incubated with R610-conjugated $\alpha$-CD4, R610-conjugated $\alpha$-CD8, FITC-conjugated $\alpha$-CD69, or PEconjugated $\alpha$-CD28 antibodies (Pharmingen, San Diego, CA) at a saturating condition for $30 \mathrm{~min}$ on ice. After being washed $3 \times$ with FACS buffer, cells were analysed using a FACScan (Becton Dickinson).

\section{Acknowledgements}

This work was supported in part by grants from NIH to DB Weiner. JJ Kim would like to thank $G$ Feiler, J Dingerdissen and V Samant.

Hodge JW, Schlom J, Donohue SJ, Tomaszewski JE, Wheeler CW, Levine BS, Gritz L, Panicali D and Kantor JA. (1995). Int. J. Cancer, 63, 231-237.

Kim JJ, Bagarazzi ML, Trivedi N, Hu Y, Kazahaya K, Wilson DM, Chattergoon MA, Dang K, Mahalingam S, Chalian AA, Agadjanyan MG, Boyer JD, Wang B and Weiner DB. (1997a). Nat. Biot., 15, 641-646.

Kim JJ, Ayyvoo V, Bagarazzi ML, Chattergoon MA, Dang K, Wang B, Boyer JD and Weiner DB. (1997b). J. Immunol., 158, 816-826.

Kim JJ and Weiner DB. (1998). Springer Sem. Immunopath., 19: $174-195$.

Labrie F, DuPont A, Suburu R, Cusan L, Tremblay M, Gomez JL and Edmond J. (1992). J. Urol., 151, 1283 1290.

Labrie F, Belanger A, Dupont A, Luu-The V, Simard J and Labrie C. (1993). Clin. Inv. Med., 16, 475-492.

Linsley PS, Grosmaire LS, Aruffo A, Damle NK and Ledbetter JA. (1991). J. Exp. Med., 173, 721-730.

Lu S, Santoro JC, Fuller DH, Hayes JR and Robinson HL. (1995). Virology, 209, $147-154$.

MacGregor RR, Boyer JD, Ugen KE, Lacy KE, Bagarazzi ML, Chattergoon MA, Baine Y, Higgins TJ, Ciccarelli RB, Coney LR, Ginsberg RS and Weiner DB. (1998). J. Inf. Dis. in press.

Mahalingam S, Kahn SA, Jabbar MA, Monken CE, Collman RG and Srinivan A. (1995). Proc. Natl. Acad. Sci. USA, 92, 3794-3798.

Mogensen SC and Virelizier JL. (1987). Interferon, 8, 55 - 84.

O'Donnell PD and Finan BF. (1989). J. Urol., 142, 1227 1229.

Pienta KJ and Esper PS. (1993). Ann. Intern. Med., 118, $793-803$.

Plautz GE, Yang ZY, Wu BY, Gao X, Huang L and Nabel GJ. (1993). Proc. Natl. Acad. Sci. USA, 90, 4645-4649.

Ray R, Thomas S and Miller DM. (1989). Oncogene, 4, $593-$ 600.

Sandra MG. (1994). J. Urol., 151, 622-628.

Schwartz RH. (1992). Cell, 71, 1065-1068.

Sobel ES, Yokoyama WM, Shevach EM, Eisenberg RA and Cohen PL. (1993). J. Immunol., 150, 673-682. 
Stack RM, Lenschow DJ, Gray GS, Bluestone JA and Fitch FW. (1994). J. Immunol., 152, $5723-5733$.

Stamey TA, Yang N, Hay AR, McNeal JE, Freiha FS and Redwine E. (1987). New Engl. J. Med., 317, 909.

Tang D, DeVit M and Johnston S. (1992). Nature, 356, $152-$ 154.

Tepper RI, Pattengale PK and Leder P. (1989). Cell, 57, $503-512$.

Tjoa B, Boynton A, Kenny G, Ragde H, Misrock SL and Murphy G. (1996). Prostate, 28, 65-69.

Townsend SE and Allison JP. (1993). Science, 259, 368 - 370.

Ulmer JB, Donnelly J, Parker SE, Rhodes GH, Felgner PL, Dwarki VL, Gromkowski SH, Deck R, DeVitt CM, Friedman A, Hawe LA, Leander KR, Marinez D, Perry H, Shiver JW, Montgomery D and Lui MA. (1993). Science, 259, $1745-1749$.

Vieweg J, Boczkowski D, Roberson KM, Edwards DW, Philip M, Philip R, Rudoll T, Smith C, Robertson C and Gilboa E. (1994). Cancer Res., 54, $1760-1765$.
Vihinen M. (1994). Biochem. \& Biophys. Res. Commun., 204, $1251-1256$.

Villoutreix BO, Getzoff ED and Griffin JH. (1994). Protein Sci., 3, 2033-2044.

Wang B, Ugen KE, Srikantan V, Agadjanyan MG, Dang K, Refaeli Y, Sato A, Boyer J, Williams WV and Weiner DB. (1993). Proc. Natl. Acad. Sci. USA, 90, 4156-4160.

Wang B, Merva M, Dang K, Ugen KE, Williams WV and Weiner DB. (1995). Human Gene Therapy, 6, 407-418.

Wang MC, Kuriyama M, Papsidero LD, Loor RM, Valenzyela LA, Murphy GP and Chu TM. (1982). Methods Cancer Res., 19, 179-197.

Watt KWK, Lee P-J, Timkulu TM, Chan W-P and Loor R. (1986). Proc. Natl. Acad. Sci. USA, 83, 3166-3170.

Wingo PA, Tong T and Bolden D. (1995). CA Cancer J. Clin., 45, 8-30.

Zagars GK and Pollack A. (1995). Urology, 45, 476-483. 